\title{
The metropolitan and the Theban silk industry: a hypothetical reconstruction*
}

\author{
Gang Wu \\ Research Center for Anatolian Civilizations (ANAMED), Koç University, \\ Istanbul \\ gang.wu@kcl.ac.uk
}

\begin{abstract}
Many theories have been proposed to explain the success of the Theban silk industry from the twelfth century onward. To contribute to this discussion in the context of recent research developments, this article explores the Theban metropolitan's hypothetical contribution to the industry through the case study of John Kaloktenes, who initiated a series of projects during his tenure (before 1166-c.1190). The analysis of three of these projects suggests that they might have been designed to support the industry. Thus, this article proposes the working hypothesis that Thebes's industrial success might have benefited substantially from the local metropolitan's active promotion.
\end{abstract}

Keywords: Byzantine silk industry; Thebes; Kaloktenes; parthenon; Balsamon

At least from the second half of the twelfth century onward, Thebes became known as a renowned centre of the silk industry within and beyond the borders of the Byzantine empire. ${ }^{1}$ Scholars have struggled to explain such an exceptional industrial success. The

\footnotetext{
* I would like to thank Professor Dionysios Stathakopoulos and Professor Alice-Mary Talbot for providing detailed and insightful comments on early drafts of this article. The final version of this article benefits significantly from the constructive suggestions of the anonymous readers. Any mistakes are entirely mine.

1 The Theban silk industry has long been the subject of scholarly attention, see E. Weigand 'Die

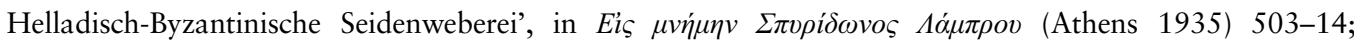

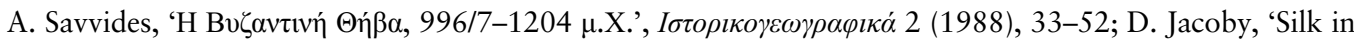
western Byzantium before the Fourth Crusade', Byzantinische Zeitschrift 84/85 (1991/1992) 452-500; A. Dunn, 'The rise and fall of towns, loci of maritime traffic, and silk production: the problem of Thisvi-Kastorion', in E. Jeffreys (ed.), Byzantine Style, Religion and Civilization: In honour of Sir Steven Runciman (Cambridge 2006) 38-71; E. de Rosen, 'The silk industry of Middle Byzantine Boeotia', Diogenes 7 (2019) 30-48.
}

(C) The Author(s), 2021. Published by Cambridge University Press on behalf of Centre for Byzantine, Ottoman and Modern Greek Studies, University of Birmingham. This is an Open Access article, distributed under the terms of the Creative Commons Attribution licence (https:/creativecommons.org/licenses/by/4.0/), which permits unrestricted re-use, distribution, and reproduction in any medium, provided the original work is properly cited.

DOI: $10.1017 /$ byz.2021.30 
most often cited factors involve Thebes's favourable natural environment: excellent water with low calcium and magnesium content, climate conditions facilitating moriculture, and the abundance of kermes dyestuff. ${ }^{2}$ However, the water and climate explanations lack scientific support. If we assume that conditions in these aspects during the Byzantine period and modern times are a useful comparison, results from hydrological studies in the 1970s suggest that the Theban water actually contained abundant magnesium ions. The water's $\mathrm{pH}$ value (around 6.5) was also below ideal for silk processing. ${ }^{3}$ The same goes for the climate. Data collected between 1951 and 1980 suggest that in Boeotia during the extended winter months (October to March), the mean temperature was $8-12^{\circ} \mathrm{C}$ and the mean precipitation amount was $300-450 \mathrm{~mm}$, while in the extended summer months (April to September), the corresponding data were $18-22^{\circ} \mathrm{C}$ and $50-200 \mathrm{~mm} .{ }^{4}$ On the premise that a temperature of $18-30^{\circ} \mathrm{C}$ and a precipitation amount of $600-2500 \mathrm{~mm}$ are optimal for moriculture, ${ }^{5}$ conditions in Boeotia would have been too cool and dry to be ideal.

Thebes's accessibility to dyestuffs, too, is hardly relevant. Although the city did produce dyed silk, ${ }^{6}$ it was predominantly Theban weaving that won praise. Niketas Choniates (c.1155-1217) clearly stated that when the Norman raiders plundered Thebes in 1147 , the artisans they captured were weavers. ${ }^{7}$ When John Tzetzes (c.1110-1180s) complimented a Theban silk textile in 1148, he mentioned only the artisans' consummate weaving skill. ${ }^{8}$ In the 1180s, Michael Choniates (c.1140-1220) implied that Constantinopolitan citizens relied heavily on Theban and Corinthian weavers to produce clothes. ${ }^{9}$ In 1198/9, Michael blamed Athens' miserable condition in part to the city's not being a weaving centre for silk textiles. ${ }^{10}$ Here, he was most

2 Weigand, 'Seidenweberei', 508; Jacoby, 'Silk', 471-2, 483; J. Shepard, 'Silks, kkills and opportunities in Byzantium: some reflexions', Byzantine and Modern Greek Studies 21 (1997) 246-57 (254); Ch. Koilakou,

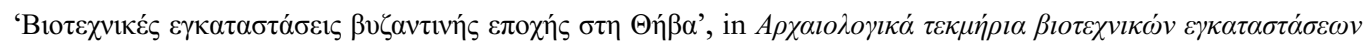

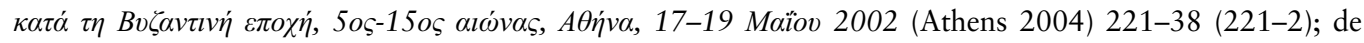
Rosen, 'Silk industry', 32-3.

3 I. Koumantakes, 'Y

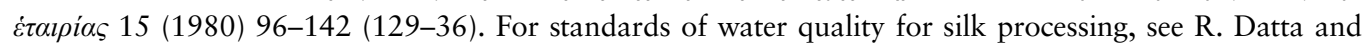
M. Nanavaty, Global Silk Industry: a complete source book (Boca Raton 2005) 136-7.

4 E. Xoplaki et al., 'The medieval climate anomaly and Byzantium: a review of the evidence on climatic fluctuations, economic performance and societal change', Quaternary Science Reviews 136, 229-52 (2368). Cf. O. Rackham, 'Observations on the historical ecology of Boeotia', The Annual of the British School at Athens 78, 291-351 (295-6).

5 Z. Ting-zing et al., Mulberry Cultivation (Rome 1988) 127.

6 Benjamin of Tudela, The Itinerary of Benjamin of Tudela: critical text, translation and commentary, ed. M. Adler (London 1907) 17.

7 Niketas Choniates, Nicetae Choniatae Historia, ed. J. van Dieten (Berlin 1975) 74, lines 48-9.

8 John Tzetzes, Ioannis Tzetzae epistulae, ed. P. Leone (Leipzig 1972) 101, lines 18-21; 102, lines 1-9.

9 Michael Choniates, Michaelis Choniatae epistulae, ed. Ph. Kolovou (Berlin 2001) 69-70, lines 63-4.

10 Choniates, Epistulae, 82, lines 11-12. 
likely taking Thebes as a reference, as he did on one other occasion. ${ }^{11}$ Thus we can conclude that the Theban silk industry's success relied primarily on its outstanding execution of weaving; there is no clear evidence that Thebes maintained an edge over other silk industrial centres in dyeing. ${ }^{12}$

Apart from natural conditions, Thebes's proximity to potential investors and thriving markets has also been brought up: the city not only was the seat of the theme of Hellas and the Peloponnese and a metropolis but maintained convenient overland transportation links and a growing population. ${ }^{13}$ The viewpoint has its merits when formulated more specifically. First, Thebes's advantageous administrative status did generate privileges: it enjoyed exemption at least from the fleet tax ( $\pi \lambda \omega i$ iovs), which was imposed upon cities like Athens. ${ }^{14}$ We may assume that with a lighter tax burden, Thebans might have had better means to purchase silk products and invest in the silk industry. Secondly, Thebes's inland location would have made it an inferior transportation hub compared to nearby littoral settlements with strong commercial engagement, such as Corinth, Chalkis, Vonitza, and Athens. Nevertheless, as piracy increasingly plagued the region's littoral areas from the late eleventh century, ${ }^{15}$ the inland location would have ensured relative security and facilitated the industry's growth. ${ }^{16}$ A testimony to this geographical leverage is the city's neglected defensive infrastructure, which stood at odds with its administrative importance. ${ }^{17}$ Thirdly, regarding population, we should keep in mind that in the twelfth century, Thebes ranked lowest among the regional metropolitan seats, after Corinth, Athens, and Naupaktos. ${ }^{18}$ Its population was estimated at only between 4000 and $5000,{ }^{19}$ while contemporary Thessalonike may have reached 150,000 and Constantinople between 300,000 and

11 Choniates, Epistulae, 89, lines 53-4. In this case, Michael was comparing Athens' heavy tax burden with the privilege Thebes enjoyed in the same aspect.

12 Shepard, 'Some reflexions', 254.

13 Jacoby, 'Silk', 471; Shepard, 'Some reflexions', 254.

14 See n. 11.

15 C. Hatzidimitriou, 'The decline of imperial authority in southwest central Greece and the role of 'Archontes' and bishops in the failure of Byzantine resistance and reconquest 1180-1297 A.D.' Diss. PhD Columbia University 1988, 38-83.

16 It was in this context that sometime before 1143 the bishop of Argos decided to transfer a convent near Nauplion to an inland location, see J. Thomas and J. Hero (eds), Byzantine Monastic Foundation Documents: A complete translation of the surviving founders' typika and testaments (Washington D.C. 2000) (hereafter BMFD), 961.

17 Niketas Choniates failed to mention any resistance and defensive facilities in Thebes against the Normans in 1147, while in Corfu, Monemvasia and Corinth, such infrastructures were more or less hinted at, see Choniates, Historia, 73-5.

18 J. Darrouzès, Notitiae Episcopatuum Ecclesiae Constantinopolitanae: Texte critique, introduction et notes (Paris 1981) 291-381.

19 E. de Rosen, 'The economic fate of urban settlements in Rhomanian Boeotia, Thessaly, and Western Macedonia (783-1204)', Diss. PhD University of Birmingham 2018, 96-7. 
$400,000 .{ }^{20}$ It seems that Thebes was a relatively small settlement with limited ecclesiastical prestige, restricted in local human resources, market access, and investments. A more compelling impetus in terms of the population seems to have been the city's immigrants. Those from southern Italy, where sizable moriculture and sericulture industries existed, may have brought their industrial resources and experience. ${ }^{21}$ Women like the Naupaktians who came to Thebes during the first half of the eleventh century may have contributed to the industry's female labourers. ${ }^{22}$ The sizeable Jewish community in Thebes, which had participated in silk manufacture according to Benjamin of Tudela's testimony, was probably also the result of recent immigration. ${ }^{23}$ The Jewish population reached two thousand in the 1160s, making it the empire's second-largest Jewish community (after Constantinople, c.2500) and undoubtedly made up a significant proportion of the local inhabitants. ${ }^{24}$

Recently, Theresa Shawcross, in a study focusing on the metropolis of Athens, has convincingly shown that metropolitans in Greece during the decades before the Latin conquest were committed to improving their dioceses' economic status. ${ }^{25}$ Meanwhile, underexplored evidence concerning early thirteenth-century Naupaktos indicates that the episcopal administration, led by its metropolitan, may have played a prominent role in fostering the local silk industry: it not only had strong demand for silk products but owned many of the local mulberry plantations and maintained directly affiliated groups of textile artisans, some of whom possibly oversaw textile production for the metropolitan episcopate. ${ }^{26}$ Regarding the Theban silk industry, a major economic sector for Thebes, ${ }^{27}$ the above research developments imply that the metropolitan may have played a role in its success. Existing scholarship often speculates that the profit-driven local aristocrats were the primary promoters of the Theban silk industry: they were not only raw material suppliers but entrepreneurs who provided the workshops, housing, industrial implements, and salaries for the silk artisans and marketed the end products. ${ }^{28}$ In this context, the above metropolitan hypothesis

20 A. Laiou, 'The human resources', in A. Laiou (ed.) The Economic History of Byzantium: from the seventh through the fifteenth century (Washington D.C. 2002) 47-55 (51).

21 Jacoby, 'Silk', 480; A. Guillou, 'La soie du Katepanat d'Italie', Travaux et Mémoires 6 (1976) 69-84.

22 J. Nesbitt and J. Wiita, 'A confraternity of the Comnenian era', Byzantinische Zeitschrift 68 (1975) 36084 (378). Naupaktos was a well-attested centre of the silk industry in the early thirteenth century, see below.

23 Jacoby, 'Silk', 485-7.

24 Benjamin of Tudela, Itinerary, 17, 24.

25 T. Shawcross, 'Golden Athens: Episcopal wealth and power in Greece at the time of the crusades', in N. Chrissis and M. Carr (eds) Contact and Conflict in Frankish Greece and the Aegean, 1204-1453 (London 2014) 65-95.

26 G. Wu, 'The silk industry around Naupaktos and its implications', Byzantinische Zeitschrift 115 (2022) forthcoming.

27 For a sceptical stance on the silk industry's status compared to traditional sectors like agriculture and pastoralism, see Dunn, 'The rise and fall', 53-7; de Rosen, 'Silk industry', 35-6.

28 M. Angold, 'Archons and dynasts: local aristocracies and the cities of the later Byzantine empire', in M. Angold (ed.) The Byzantine Aristocracy IX to XIII Centuries (Oxford 1984) 236-53 (240); Jacoby, 'Silk', 476-80; Shepard, 'Some reflexions', 254. 
brings a new and promising perspective in interpreting the Theban silk industry, from which we may also draw inferences to further our understanding of the Byzantine silk industry as a whole. In what follows, we will take this hypothesis into serious consideration, exploring the hypothetical contribution of the metropolitan of Thebes to the silk industry by seeking possible corroborations from surviving historical sources.

\section{John Kaloktenes and Thebes}

Thebes rose to the status of metropolis in the tenth century. ${ }^{29}$ Several metropolitans of Thebes are attested in the sources, but in most cases we only know their names at most. ${ }^{30}$ Fortunately, one of them is relatively well attested: John Kaloktenes, who is first mentioned as the metropolitan of Thebes in 1166 and probably died between 1186 and $1193 .{ }^{31}$ Our knowledge of Kaloktenes derives from scattered sources. The manuscripts containing the earliest known vita and akolouthia of Kaloktenes were lost during the Greek Revolution. The two existing versions of the vita and akolouthia, one included in a manuscript and the other in a published brochure, were nineteenth-century reproductions based on the lost manuscripts. ${ }^{32}$ Essentially modern works, their credibility should be treated with caution; where their accounts are supported by quotations from the lost manuscripts or corroborated by archaeological findings, the information they record can be considered reliable. Through his name and the metropolitan title, Kaloktenes has also been identified in various records from the second half of the twelfth century: a participant in councils convened in Constantinople, ${ }^{33}$ a clerical personality remembered in the synodikon of the local church, ${ }^{34}$ the addressee of a letter from Michael Choniates, ${ }^{35}$ and the owner of three surviving seals. ${ }^{36}$ Regarding his projects during his metropolitan tenure, some are implied in the extant versions of his vita and akolouthia. Others were recorded by his contemporaries, including John Apokaukos (c.1155-1233) and Theodore Balsamon (1130s-1195).

29 Darrouzès, Notitiae, 83, 293. Cf. J. Darrouzès, 'Remarques sur des créations d'évêchés byzantins', Revue des études byzantines 47 (1989) 209-37 (229).

30 Nesbitt and Wiita, 'Confraternity', 365, lines 40-1; M. Jeffreys et al., Prosopography of the Byzantine World, 2016, http://pbw2016.kdl.kcl.ac.uk (King's College London 2017), Ioannes 262, Petros 129, Petros 20119, Niketas 20286, Konstantinos 20561; Choniates, epistulae, 113-4.

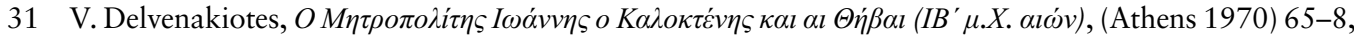
76.

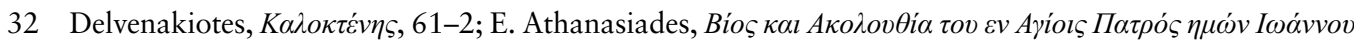

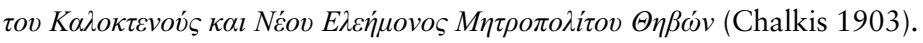

33 PG 140:237B, 241D, 260B, 269A-B, 273A, 276D; L. Petit, 'Documents inédits sur le concile de 1166', Vizantiiskii vremennik 11 (1904) 465-93 (488), line 24.

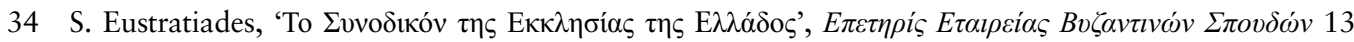
(1937) 3-29 (15).

35 Choniates, epistulae, 22.

36 Jeffreys, Prosopography, Ioannes 20344. 
In addition to the existence of available sources, John Kaloktenes also happens to be an ideal subject for our investigation. His tenure largely coincided with the historical stage Shawcross has discussed, and it predated the documented Naupaktian silk industry by just a few years, thus constituting a compelling case for comparative examination. Kaloktenes' time as metropolitan witnessed the apogee of the Theban silk industry. By the time he assumed the metropolitan see, sometime before 1166, Thebes must have recovered from the disastrous Norman raid of 1147 , and in the 1160s, Benjamin of Tudela could attest to a large Jewish community of silk and purple textile artisans in the city. ${ }^{37}$ In the instructions the Genoese authorities gave their envoy in the early 1170s, the right to trade silk in Thebes, previously enjoyed by the Venetians, was among the privileges demanded of the Byzantine emperor. ${ }^{38}$ In the mid-1180s, Thebes was described as a primary place of origin for textiles used in Constantinople. ${ }^{39}$ In 1195, shortly after the death of Kaloktenes, Theban silk textiles were considered by the Turks the best in Byzantium. Simultaneously, the Byzantine emperor had been receiving a sizable yearly contribution of silk textiles from Thebes. ${ }^{40}$ These indicate that Thebes had now surpassed Constantinople as the empire's primary centre of the silk industry. Apart from textual sources, coins recovered from the archaeological site of a silk workshop in Thebes provide additional evidence for the industry's developmental trajectory. ${ }^{41}$ While they span from the ninth/tenth to the fourteenth century, roughly half of those dated before 1204 come from the reign of Manuel I Komnenos (1143-85). ${ }^{42}$ Thus, the workshop's Byzantine history must have culminated around this period, which coincides with Kaloktenes' tenure. In this case, if supporting the silk industry was metropolitan policy, we are very likely to find its traces during Kaloktenes' term.

\section{Kaloktenes' initiatives}

John Kaloktenes' major initiatives can be summarised as follows. From the testimony of his vita and akolouthia, he constructed an aqueduct in Thebes as well as a church for the Mother of God, which may have functioned as the metropolitan church. ${ }^{43} \mathrm{He}$ also converted a part of the Theban Jewish population to Christianity and contributed to the city's philanthropic infrastructure, including the foundation of a public retirement home, poor-houses, and hospitals. ${ }^{44}$ However, only the church and aqueduct projects

37 Benjamin of Tudela, Itinerary, 17.

38 G. Bertolotto, 'Nuova serie di documenti sulle relazioni di Genova coll'impero Bizantino', Atti della Società ligure di storia patria 28 (1898) 338-573 (347-8).

39 See n. 9.

40 Choniates, Historia, 461, lines 28-36.

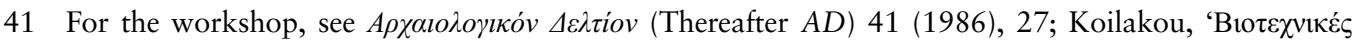

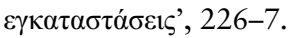

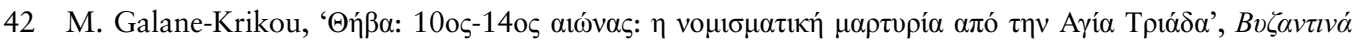

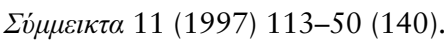

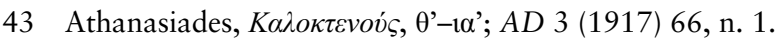

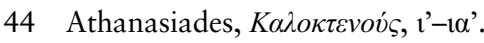


can be corroborated by additional evidence, ${ }^{45}$ for which reason we will include only them in our investigation. From John Apokaukos, we learn that Kaloktenes converted a male monastery in Thebes into a convent and named it the convent of Dekane after the abbess he appointed. ${ }^{46}$ Theodore Balsamon attested that Kaloktenes appointed new bishops and established in Thebes a parthenon ( $\pi \alpha \rho \theta \varepsilon v \omega$ v), a female religious foundation accommodating virgins. ${ }^{47}$

Apart from sponsoring the church foundation and appointing bishops, none of these projects was a common endeavour for Byzantine metropolitans. The aqueduct in Thebes is among the few, if any, attested aqueducts from the middle Byzantine period. ${ }^{48}$ Kaloktenes' conversion of a male monastery into a convent is the only concrete case of a metropolitan undertaking such conversions. ${ }^{49}$ According to Balsamon, parthenones must have been almost extinct by the time of Kaloktenes, since they no longer existed even in Constantinople, the empire's paramount centre for female religious foundations. ${ }^{50}$ Kaloktenes was probably the first founder of a parthenon in a long time. These rather unusual projects were undertaken in an era when nonconformity could ruin a metropolitan's career, an atmosphere Kaloktenes must have sensed. The two councils he attended in Constantinople in 1166 and 1170 were aimed at suppressing deviations from beliefs that the emperor considered orthodox. Kaloktenes himself certainly witnessed the condemnation of George, metropolitan of Nicaea, and Constantine, metropolitan of Corfu, who expressed opposition to established dogma. $^{51}$ In addition, Kaloktenes himself may have been condemned for nonconformity. His above-mentioned appointment of bishops was effected without the permission of the Great Synod of Constantinople. For this reason, a synod in the 1170 s concluded that the appointment went against canonical provisions, although the penalty Kaloktenes received remains unclear. ${ }^{52}$ Under these circumstances, Kaloktenes' rather exceptional projects in Thebes would have made him a bold reformer.

45 For the archaeological evidence of the church, see $A D 3(1917) 66$, n. 1 . For that of the aqueduct, see $A D$ 3 (1917) 123, n. 2. For excerpts from the lost manuscripts about the aqueduct, see Athanasiades, Ka

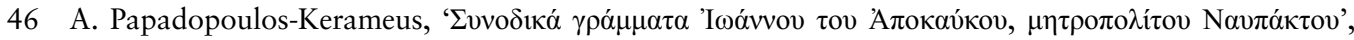

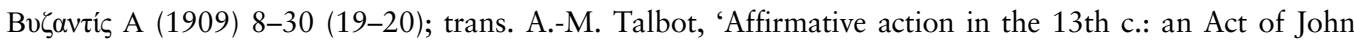
Apokaukos concerning the Blachernitissa Monastery in Arta', in A.-M. Talbot, Women and Religious Life in Byzantium (Aldershot 2001) 399-409 (402-9).

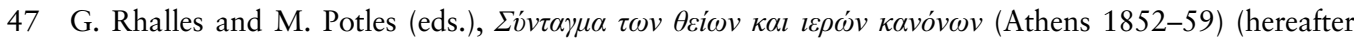

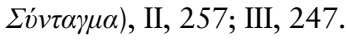

48 R. Ousterhout, 'Secular Architecture', in H. Evans and W. Wixon (eds), The Glory of Byzantium: Art and culture of the Middle Byzantine era, A.D. 843-1261 (New York 1997) 192-9 (196).

49 Seven cases of such conversions have been identified, see A.-M. Talbot, 'The conversion of Byzantine monasteries from male to female and vice-versa', in C. Scholz and G. Makris (eds.), Polypleuros Nous: Miscellanea für Peter Schreiner zu seinem 60. Geburtstag (Munich 2000) 360-4 (360-2).

50 A.-M. Talbot, 'A comparison of the monastic experience of Byzantine men and women', in Talbot, Women and Religious, 1-20 (18).

51 PG 140:260B; Petit, '1166', 488, line 24.

$52 \Sigma \dot{v} v \tau \alpha \gamma \mu \alpha$, III, 247. 


\section{Interpreting the initiatives}

To summarise what we have observed so far: by the time Kaloktenes became the metropolitan of Thebes, the Theban silk industry, the city's economic engine, had recovered from the destruction inflicted by the Normans and was on track to reach its acme by the end of his tenure. At about the same time that his counterpart in Athens was committed to building up the diocesan economy, and the metropolitan of Naupaktos was a leading promoter of the local silk industry, Kaloktenes, an innovative and daring figure, introduced a series of unconventional initiatives in Thebes. Although the motivations behind these initiatives are not specified in the records, context leads us to the hypothesis that these initiatives may have stemmed from Kaloktenes' concern for the economy of his diocese, especially its silk industry. The hypothesis appears tenable if we delve into the possible connections between these initiatives and the silk industry.

\section{The aqueduct}

The aqueduct is unlikely to have been intended to serve agricultural needs, which undoubtedly would have called for substantial water investment. Its remains, consisting of twenty arches, were identified outside the southern end of the Kadmeia. ${ }^{53}$ The location indicates that the aqueduct was designed to introduce water into the Kadmeia, which was certainly not an intensively cultivated area in Kaloktenes' diocese. $^{54}$ The increasing population of Thebes, as implied by various evidence, ${ }^{55}$ may have boosted the city's overall water consumption. However, the relatively small size of its population makes it unlikely that the population was the project's primary stimulus. Instead, the aqueduct might well have been introduced to meet the need of the silk industry. The Kadmeia must have contained a significant part of the silk-processing workshops in Thebes, some of which have been identified through their archaeological remains. ${ }^{56}$ The operation of these workshops would have required large quantities of water. Records describing the region's contemporary silk industrial practice suggest that the cocoons were boiled in hot water before being processed into threads. ${ }^{57}$ Comparable details of the dyeing process have not yet been found in Byzantine sources, but we can reasonably assume that it must have also included water

$53 A D 3$ (1917) 123, n. 2. The remains were demolished by the early twentieth century.

54 Agriculture was concentrated in the suburban plain areas, see N. Svoronos, 'Recherches sur le cadastre byzantin et la fiscalité aux XIe et XIIe siècles: le cadastre de Thèbes', Bulletin de correspondance hellénique 83 (1959) 1-145 (46-8, 53-5).

55 Izdebski et al., 'Exploring Byzantine and Ottoman economic history with the use of palynological data: a quantitative approach', Jabrbuch der Österreichischen Byzantinistik 65 (2005), 1-54 (26-7, 40-1); A. Harvey, 'Economic expansion in central Greece in the eleventh century', Byzantine and Modern Greek Studies 8 (1982-83) 21-8 (24-7).

56 Louvi-Kizi, 'Thebes', 635-7.

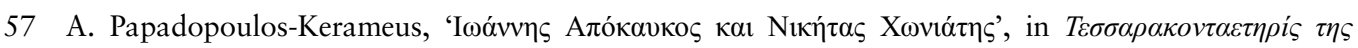

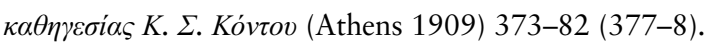




\section{Gang Wu}

use in various stages given what we know about the better-attested practice in antiquity. ${ }^{58}$ The local silk industry's expansion would have resulted in a dramatic surge in demand for water in Kadmeia, which seems to be the most compelling reason for Kaloktenes' introduction of an aqueduct.

\section{The Conversion}

Kaloktenes' conversion of a male monastery into the convent of Dekane needs to be examined in context. On average, a major Byzantine provincial centre (and this includes Athens) maintained two convents at most in any given period. ${ }^{59}$ In Epiros in $1224 / 5$, the lack of convents forced nuns to stay in the forecourts of churches in dilapidated shacks which had space only for broken-down beds. ${ }^{60}$ In contrast, during the tenure of Kaloktenes, Thebes, despite its much smaller population compared to Athens and Naupaktos, ${ }^{61}$ seems to have maintained a disproportionately large number of convents. We are informed by Apokaukos that when Kaloktenes inaugurated the convent of Dekane, there were already 'many $(\pi \circ \lambda \lambda \tilde{\omega} v)$ other female convents in Thebes. ${ }^{62}$ If we take this 'many' as at least three and add the convent of Dekane, Thebes then hosted at least four convents. Archaeological evidence implies that there might have been a surge in the number of monasteries in Thebes around the same period: among the six Theban monasteries identified through their remains, five have been dated to the twelfth and early thirteenth centuries. ${ }^{63}$ The substantial number of convents Apokaukos implied must have constituted a part of the picture. We do not know if there were other convents founded under Kaloktenes' direct patronage, but by converting a male monastery into a convent, he had contributed to an apparent expansion of convents in Thebes.

Could the coincidence of such an expansion with a thriving silk industry point to a correlation? The hypothesis may seem plausible if we clarify the possible connections between the two developments. The silk industry's success, as we have mentioned, relied upon its superior execution of weaving, which seems to have been conducted primarily by women. John Tzetzes attributed the delicacy of his Theban silk textile to the Theban women's incomparable weaving skills. ${ }^{64}$ According to Niketas Choniates, the people taken away by Norman raiders in 1147 were Theban female weavers. ${ }^{65}$ Three decades later, when the French poet Chrétien de Troyes described a working scene of three hundred captive silk weavers, which has been convincingly

58 R. Forbes, Studies in Ancient Technology (Leiden 1964) 99-150.

59 Talbot, 'Comparison', 1-2, 18.

60 Talbot, 'Affirmative action', 399, 405.

61 See n. 19.

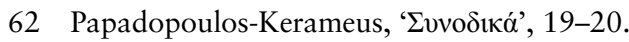

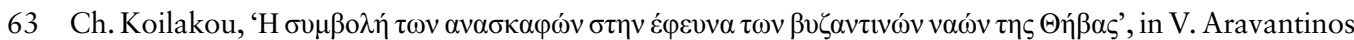

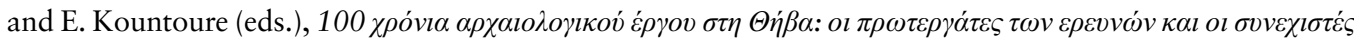

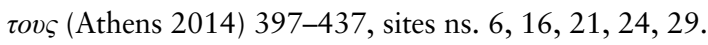

64 See n. 8 .

65 Choniates, Historia, 74, lines 48-9. 
demonstrated as depicting the abducted Theban artisans, ${ }^{66}$ he also specified that they were all women. ${ }^{67}$ That the Theban weavers' gender was highlighted is not surprising: Byzantine sources tend to present weaving as women's domain. ${ }^{68}$ The suggestion is unlikely an unrealistic literary topos; ${ }^{69}$ ethnographic studies have suggested that women dominating textile weaving is common worldwide. ${ }^{70}$ Following this vein, we may conclude that supporting women in weaving work must have been the key to promoting the Theban silk industry.

Here we need to bring forward how the female artisans of silk textiles were organised in Thebes. The sources are not informative in this regard, and we have to resort to educated guesswork. We have mentioned historians' speculation favouring aristocrat-sponsored workshops. What has been neglected in the current scholarship is the possible involvement of female religious foundations. By late antiquity, female ascetics in religious foundations were frequently attested as working in textile production and generating income by selling the surplus. ${ }^{71}$ From the early twelfth century on, we are informed by the extant typika of convents that the handiwork of nuns, an essential part of their daily lives, was predominantly related to textile manufacturing. ${ }^{72}$ For those 'labouring' nuns, such work was intensive and conducted under close supervision. The monastic institution controlled the means of production and absorbed all the products, forming a system of labour exploitation. ${ }^{73}$ The nuns' products were not limited to cheap textiles for everyday use but must also have included luxury items. Theodore Balsamon implied that in his contemporary kelliotic convents, the predominant type of convents at that time, ${ }^{74}$ garments made of silks and adorned with gold and stones were used in nuns' induction rites. ${ }^{75}$ His record suggests

66 K. Ciggaar, 'Chrétien de Troyes et la "matière byzantine "; les demoiselles du Château de Pesme Aventure', Cahiers de civilisation médiévale 128 (1989) 325-31.

67 Chrétien de Troyes, Le Chevalier au Lion, ed. D. Hult (Paris 1994) 370-2.

68 A. Laiou, 'The role of women in Byzantine society', Jahrbuch der Österreichischen Byzantinistik 31/1 (1982) 233-60 (244-5).

69 Jacoby, 'Silk', 468.

70 F. Sorber, 'Weaving techniques and tools', in N. Paydar and I. Grammet (eds.) The Fabric of Moroccan Life (Washington, D.C. 2002) 139-41 (139) (Berber weaving); P. Davies, Antique Kilims of Anatolia (New York 2000) 47-51 (Turkish weaving). In other weaving practices, see F. Zhao et al. (eds), A World of Looms: weaving technology and textile arts (Hangzhou 2019) 33, 67, 81, 101, 103, 139-40. The predominant Byzantine weaving practice, adopted also in the Theban silk industry, very much resembled that of traditional Berber and Turkish weaving, see G. Wu, 'How did Byzantines weave? A synthesis of textual, pictorial, ethnographic, and archaeological evidence', Greek, Roman, and Byzantine Studies 61 (2021) 368-95.

71 S. Elm, Virgins of God: the making of asceticism in Late Antiquity (Oxford 1994) 73, 75, 99, 294.

72 BMFD, 649-724, 1462-82, 1512-78.

73 C. Galatariotou, 'Byzantine women's monastic communities: the evidence of the typika', Jahrbuch der Österreichischen Byzantinistik 38 (1988) 263-90 (273).

74 See below.

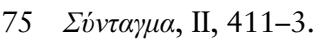


that in the second half of the twelfth century, the skill of producing luxurious silk textiles must have been highly valued in most of the convents within the empire. Given that the induction was only one of the many rites performed in convents that might have included the use of high-end textiles, nuns must have extensively engaged in producing such textiles to meet demand.

More importantly, the nuns' handiwork could be market-oriented. The typikon of the convent of Christ Philanthropos in Constantinople (dated c.1307) forbade nuns from doing their own private handiwork and acting as businesswomen, ${ }^{76}$ indicating the prevalence of nuns selling their products themselves. The typikon of the convent of the Pantanassa at Baionaia (dated c.1400) also implied that the works of nuns could bring them income presumably through the sale of their products. $^{77}$ In our research period, the commercialisation of product surplus in major monastic centres like Patmos and Athos is attested as prevalent. $^{78}$ Around Thebes, convents exploring ways to gain additional revenue was certainly not rare. ${ }^{79}$ The reform movement, led by the prominent monastic founder Meletios the Younger (fl. c.1050-c.1105), advocating the rejection of both private and communal possessions was probably a backlash to monastic communities' pursuit of secular profits. ${ }^{80}$ In cities with a surging silk industry like Thebes, convents embraced the opportunities and engagement in market-oriented work is attested. ${ }^{81}$ In this context, we may suppose that for Theban convents without significant means, producing and selling the textile surplus from nuns' everyday work could have emerged as a common way to sustain their maintenance. The convent Kaloktenes converted, like many of its counterparts likely to have been founded in Thebes around the same period, may have helped accommodate more women active in silk production. If aristocrat-sponsored workshops were indeed an organisational form of the Theban silk industry, founding convents were certainly a much more logical and feasible alternative, given Kaloktenes' capacity as a metropolitan, for him to meet his diocese's industrial demand.

\section{The parthenon}

As we have already noted, the parthenon, a type of foundation almost abandoned in the empire by Kaloktenes' time, accommodated women consecrated as virgins. According to Balsamon, the virgins dedicated themselves to God and disavowed marriage, following

\footnotetext{
$76 \quad B M F D, 1387$.

77 BMFD, 1471.

78 K. Smyrlis, La fortune des grands monastères byzantins. (fin du Xe-milieu du XIVe siècle) (Paris 2006) 223-5.

79 For the example of exploiting the icon they owned, see N. Oikonomides, 'The holy icon as an asset', Dumbarton Oaks Papers 45 (1991) 40-4.

80 D. Krausmüller, 'Take no care for the morrow! The rejection of landed property in eleventh- and twelfth-century Byzantine monasticism', Byzantine and Modern Greek Studies 42 (2018) 45-57 (51-7).

81 This was the case in fifteenth-century Florence, see S. Strocchia, Nuns and Nunneries in Renaissance Florence (Baltimore 2009) 116-26.
} 
the practice of the consecration of virgins. ${ }^{82}$ They resembled ascetics but were considered laywomen, retaining features distinguishing them from nuns: they neither bore monastic habit and tonsure nor took monastic vows. ${ }^{83}$ Thus, the foundation of the Theban parthenon can be seen as a revival of a Christian tradition that had fallen into desuetude.

The hypothetical relevance between the parthenon and the Theban silk industry can be understood, first of all, through its similarity to the convent. Both the parthenon and the convent derived from the same widely documented model of ascetic community, in which residents were involved in textile production and profiting from selling the surplus. ${ }^{84}$ Although later developments separated the two forms of community, ${ }^{85}$ their members must have retained similar day-to-day practices: Balsamon found it necessary to reiterate in his scholia the virgins' identity and their differences with nuns. ${ }^{86}$ The virgins must have engaged in textile-related manual labours in the parthenon as nuns did in the convent. Textile products from the Theban parthenon could have also been easily adapted to market needs as those from the Theban convents possibly were.

More importantly, the parthenon is more likely to have been active in the silk industry than a convent. From a comparative perspective, this point can be illustrated through the parthenon's resemblance to the beguinage in the contemporary Latin West. A beguinage, first recorded in 1230 in Aachen, is a foundation to accommodate beguines, women who led a life of devotion but maintained a lay identity without taking solemn vows as nuns did. ${ }^{87}$ Originated in the southern Low Countries in the late twelfth century, the beguine movement spread across Europe and reached its peak in the late thirteenth century. Most beguines worked in the textile industry, including silk production, ${ }^{88}$ much more extensively than traditional nuns, whose work was mainly confined to embroidering vestments or manufacturing tapestries for religious use. ${ }^{89}$ Beguinages also provided the expanding textile industry with a cheap and flexible labour force by attracting rural labour to cities. ${ }^{90}$ The revival of the parthenon in Thebes and the beguine movement are comparable in the sense that they were

$82 \Sigma v ́ v \tau \alpha \gamma \mu \alpha$, II, 315, 256; III, 60, 309, 402, 410, 590; IV, 141-2. For in-depth discussions of the practice as understood by Balsamon, see G. Wu, 'Another Parthenon: Female lay spirituality in twelfth-century Thebes', in A. Vavaliou, C. Meynell, and D. Gallaher (eds), Contested Heritage: Adaptation, restoration, and innovation in the Late Antique and Byzantine world (Leiden 2022, forthcoming).

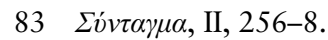

84 See n. 71.

85 When the parthenon was first mentioned in the fourth century, its difference from the monastery was not as clear, see Elm, Virgins, 98, 186-7, 207-11.

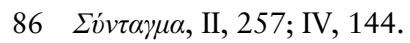

87 W. Simons, Cities of Ladies: Beguine communities in the medieval Low Countries, 1200-1565 (Philadelphia 2001) ix; T. Miller, The Beguines of Medieval Paris: gender, patronage, and spiritual authority (Philadelphia 2014) 1-2.

88 Miller, Beguines, 62, 65-7.

89 For example, Simons, Beguine, 86, 197, n. 173.

90 Simons, Beguine, 115, 142; Miller, Beguines, 47-8. 
contemporary socio-religious developments in growing urban centres with thriving textile industries. Furthermore, the virgins in the parthenon shared striking similarities with the beguines as a distinct religious group from nuns: both were laywomen who did not take monastic vows like nuns and were bound only by a vow of chastity. Thus, theoretically, the Theban parthenon may have supported the local textile industry as beguinages did. ${ }^{91}$

In addition, compared with the convent, the parthenon maintained distinctive features that could much better have accommodated industrial needs. We have mentioned that the virgins differed from nuns in monastic habits, tonsure, and vows. The habit and tonsure made a woman visibly a nun and allowed others to supervise and bear witness for her. ${ }^{92}$ Therefore, she had to be determined enough to bear the discipline her actions might incur. In contemporary ecclesiastical writings, assuming the habit signified abandonment of the worldly life, ${ }^{93}$ the tonsure the renunciation of her previous possessions. ${ }^{94}$ The monastic vows of a nun essentially included those of poverty (to renounce the world and what was in it), obedience (to endure all the difficulties and tribulations of monastic life until death), and chastity (to retain virginity). ${ }^{95}$ In the context of the twelfth century, tonsure and the vow of poverty together would have compelled her to forswear the possessions she acquired both before and after embracing the monastic life. ${ }^{96}$ By contrast, none of the above characterised a virgin in the parthenon. She was only obliged to keep a vow of chastity which was certainly less binding: the vow was not the public

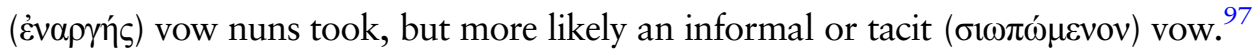

Such differences would have rendered the parthenon much more attractive than the convent to textile artisans. For ordinary women around Thebes, to abandon worldly life like a nun must have called for some determination. In late eleventh-century Phokis, the brother of Nicholas the pilgrim would respond to Nicholas' repeated invitations to renounce the worldly life with contempt and stern rejections. ${ }^{98}$ As a less rigid and disruptive alternative which still offered the possibility of becoming a nun and

91 There is no clear evidence that the Theban parthenon directly influenced the beguine movement or vice versa. They were more likely independent developments led by comparable socioeconomic conditions and needs. A possible tenuous link between the two may have been that the rampant Catharism in the Low Countries, which has been considered as a catalyst of the beguine movement, was reported in 1143 as originated from Graecia, a word that can be interpreted as the East, Byzantium or Greece, see Simons, Beguine, 17.

92 In terms of the monastic habit, see PG 31:977D-980A.

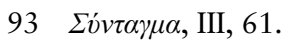

94 Eustathios of Thessalonike, De emendanda vita monachica, ed. K. Metzler (Berlin 2006), 70, lines 16$19,3-8$.

95 E. Herman, 'Die Regelung der Armut in den byzantinischen Klöstern', Orientalia Christiana periodica 7 (1941) 406-60 (419-21).

96 Eustathios, monachica, 70.

$97 \Sigma v v \tau \alpha \gamma \mu \alpha, \mathrm{IV}, 144-6$.

98 O. Limone, Santi monaci e santi eremiti: Alla ricerca di un modello di perfezione nella letteratura agiografica dell'Apulia normanna (Galatina 1988) 138-9. 
guaranteed a life not inferior to that of a nun, ${ }^{99}$ life as a consecrated virgin may well have been more suitable for those seeking a supportive community to settle in but feeling unprepared to embrace the challenges of monastic life. Women who had trained as textile artisans out of worldly considerations and who did not opt for monastic life from the outset were likely to have belonged to this category. Furthermore, virgins may have been more motivated to improve their productivity and skills. Although nuns selling their products would have generated income, as we have noted, bound by the vow of poverty, they were not allowed to own possessions, at least beyond everyday necessity. Their avowed commitment to renouncing the world also severely restricted their spending the output on their relatives. ${ }^{100}$ In the case of the virgins operating without such restrictions, their output could have benefited themselves or their relatives directly, leading to stronger motivation. This may have been essential, considering that textile crafts like weaving took years to master; ${ }^{101}$ for making luxurious silk textiles, the training process could only have been more rigorous. Finally, products from the parthenon could be better commercialised than those from the convent. Trading by monastics was considered a sin of acquiring possessions and an engagement with the secular world they had renounced. ${ }^{102}$ Thus, the Pantanassa typikon, the only extant typikon of a convent that provides rules on nuns' commercial behaviour, enforced close surveillance when trading took place. ${ }^{103}$ Moral and practical constraints like these did not apply to the parthenon's virgins.

The parthenon also differed from the convent in the members' way of life. Contemporary monasteries around Thebes seem predominantly to have adopted a kelliotic system, in which each monk or nun had a separate cell. The monastery of Hosios Meletios, founded by Meletios the Younger on the border of Boeotia and Attica,

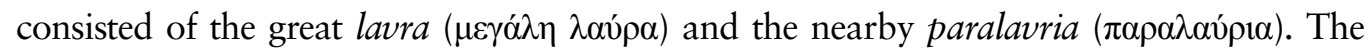
paralavria was implied to comprise secluded cells, an arrangement most likely adopted also by the great lavra, as indicated by the root lavr- they share. ${ }^{104}$ Monks in Hosios Meletios probably resided in their own individual cells. In a monastery primarily modelled upon Hosios Meletios in Areia (east of Nauplion, Peloponnese), each monk

99 According to the canonical tradition, virgins had a recognized place in the ecclesiastical hierarchy; they were governed and provided for by the bishop and had the prospect of becoming nuns and deaconesses, see

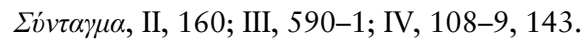

100 BMFD, 1471.

101 I. Reswick, Traditional Textiles of Tunisia and Related North African Weavings (Los Angeles 1985) 6879; Davies, Kilims, 47-51. Cf. n. 70.

102 Eustathios, monachica, 72; BMFD, 1471.

103 BMFD, 1471.

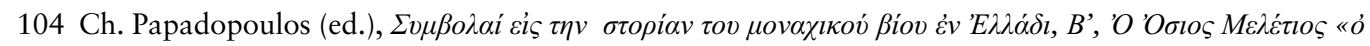

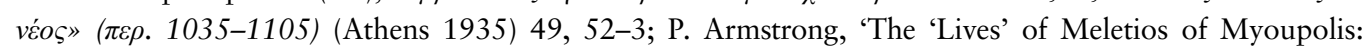
Introduction, translation and commentary', MA thesis, The Queen's University of Belfast 1988, 94-5, 102, $160-3$. 
seems to have had his own cell. ${ }^{105}$ We may assume that other nearby monasteries founded by Meletios and his disciples probably adopted the same arrangement. ${ }^{106}$

In kelliotic monasteries, handiwork was carried out mainly in individual cells rather than defined workshops. The typikon of the convent of Bebaia Elpis in Constantinople (dated 1327-35) stipulated that in a nun's spare time, she should stay in her own cell praying, reciting or reading the psalms, or performing textile-related manual labour. ${ }^{107}$ Closer to Thebes, the typikon of the monastery in Areia provided that each monk should go to his own cell and engage in handiwork after meals. ${ }^{108}$

The virgins in the parthenon lived differently. According to Balsamon, they ate and slept in the same place. ${ }^{109}$ In other words, instead of occupying their own individual cells, the virgins shared a dormitory. Such a monastic lifestyle must have been rare at that time: as Balsamon describes it as almost abandoned and only preserved in cenobitic convents and Latin monasteries. ${ }^{110}$ The typikon of one such convent fortunately survives to the present: that of the Kecharitomene (dated 1110-16). The typikon commanded the nuns to sleep in dormitories. This arrangement was intended to make the residents visible to one another so that the indolent might imitate the more industrious in virtue and good works. The typikon implied that an ideal dormitory was a room consisting of two sections: one for sleep and the other for handiwork. The handiwork was managed and supervised by the abbess herself. To ease the toil while working, one of the nuns would read a portion of the Scriptures chosen by the abbess. ${ }^{111}$

The $c .900$ vita of St Theodora of Thessalonike (812-92) provides additional details about such a dormitory system through the example of St Stephen's convent in Thessalonike. ${ }^{112}$ The vita implies that the nuns in the convent slept together in a dormitory, and that each was assigned a sleeping location that was not subject to change without the superior's consent. The dormitory must also have been equipped with tables, benches and a furnace, given that meals were transferred from the refectory to the dormitory during cold winters. Although not specified in the vita, the dormitory probably also functioned as the place for nuns' handiwork, as in the convent of the Kecharitomene. This must have been the case during cold winters: the tables and

105 BMFD, 954, 962, 964-5, 967.

106 Armstrong, Meletios, 73, 88, 94-5. Meletios' disciple Clement founded the monastery of Sagmata in

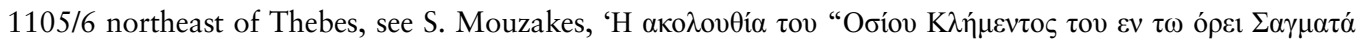

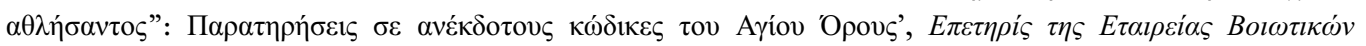

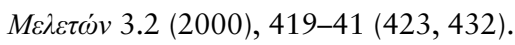

107 BMFD, 1542.

108 BMFD, 965.

$109 \sum v \dot{v} \tau \alpha \gamma \mu \alpha$, III, 410-1.

$110 \Sigma v ́ v \tau \alpha \gamma \mu \alpha$, III, 411.

111 BMFD, 671.

112 A.-M. Talbot (ed.), Holy Women of Byzantium: Ten Saints' Lives in English translation (Washington D.C. 1996) 160 . 
benches may also have been used for dining and handiwork interchangeably. Moreover, the vita implies that handiwork was done in a communal setting. ${ }^{113}$

Compared to the kelliotic system, the dormitory system the Theban parthenon adopted offered substantial benefits to textile production, especially weaving. Under the kelliotic system where the residents' handiwork was performed in individual cells, supervision was difficult, and jobbery seems to have occurred frequently. ${ }^{114}$ However, in the dormitory system, since a collective space for both sleeping and manual labour was available, the superior could implement effective supervision, as we have seen in the Kecharitomene typikon. Secondly, group work, which was critical to textile production, could be carried out within the dormitory system. To take weaving as an example, ethnological studies have shown that group work was necessary to weave on the predominant type of loom at that time. ${ }^{115}$ In the dormitory of the convent of St Stephen, operating a loom involved at least two nuns. ${ }^{116}$ Thirdly, evidence from eleventh-century Constantinople suggests that female textile artisans learned their crafts from senior artisans through rigorous training. ${ }^{117}$ The dormitory system of the parthenon would have facilitated such training: virgins were traditionally entrusted to senior virgins who would supervise them while living together, ${ }^{118}$ and indolent residents could have been effectively motivated, as we have seen in the Kecharitomene typikon. Finally, the same typikon also suggests that the dormitory system made it possible to employ a certain kind of toil-alleviating strategy like listening to the reading of Scriptures. Its efficacy can be compared to listening to music in weaving practices like the one adopted by the Theban artisans, which 'gives an emotional impetus and helps to keep a quick but steady pace in work that is characterised by its repetition and slowness. ${ }^{119}$

We may conclude by saying that Kaloktenes' seemingly aberrant revival of the parthenon in Thebes can be interpreted as an intentional step to introduce a more productive model of monastic organisation to promote the silk industry in his diocese. A comparison with the beguinage shows that the parthenon's affinity with the Theban silk industry is theoretically plausible. More specifically, if we assume that the female monastic foundations in Thebes were indeed involved in market-oriented textile production, the parthenon would satisfy industrial needs much better than the convent. The less binding lifestyle of the parthenon-based virgins could be much more attractive to women who had been trained for textile-related crafts. Moreover, the virgins could be

113 Talbot, Holy Women, 188, 190-1.

114 BMFD, 1542, 1387, 1471.

115 C. McCreary, Moroccan Loom (Santa Rosa 1975) 10, 20-1, 31, 57, 64-5; M. Naji, 'Gender and materiality in-the-making: the manufacture of Sirwan femininities through weaving in southern Morocco', Journal of Material Culture 14 (2009) 47-73 (52, 57); Reswick, Weavings, 71; Davies, Kilims, 50. Cf. n. 70. 116 Talbot, Holy Women, 188, 200.

117 A. Laiou, 'The festival of 'Agathe': comments on the life of Constantinopolitan women', in A. Laiou, Gender, Society and Economic Life in Byzantium (Hampshire 1992) III, 111-22 (111-3).

$118 \Sigma \dot{v} v \tau \alpha \gamma \mu \alpha$, III, 410.

119 Naji, 'Morocco', 64. Cf. n. 71. 
more motivated to improve their efficiency and skills; their products could also be better commercialised. Besides, the parthenon's dormitory system could make way for effective supervision and group work. A more efficient professional tutoring and a certain kind of toil-alleviating organisation were also available in this system.

\section{Concluding remarks}

Though the evidence we have is rather slim and mostly conjectural, our analysis of what little is there demonstrates that the unusual projects John Kaloktenes spearheaded in Thebes can be reasonably interpreted as designs to promote the city's silk industry. The aqueduct responded to the increasing demand for water required in silk processing. The conversion of a male monastery into a convent allowed more women to be incorporated into a workshop-like environment expedient for market-oriented silk production. The revival of the parthenon could have been a de facto institutional renovation of the rather rigid convent system to better serve the industry: it not only preserved the convent's advantageous framework but also retained distinctive features much more compatible with industrial needs. Despite the hypothetical nature of the above interpretation at the current stage, hopefully it will inspire future work in order to prove or disprove it. From the archaeological perspective, perhaps we can expect to find remains of weaving activities found in monastic contexts around Thebes as we have seen elsewhere. ${ }^{120}$ Sources corroborating aspects of Kaloktenes' metropolitan tenure are also possible. For example, if Kaloktenes indeed engaged in Christianizing Jews as his modern vita and akolouthia suggest, ${ }^{121}$ given the Theban Jewish community's large size and attested involvement in the silk manufacture, the possible relevance between the Christianisation and the silk industry will also be worthwhile delving into. In any case, what we have now learned through the case studies of contemporary Athens, Naupaktos, and Thebes suffices to show that metropolitans' roles in the silk industry in Western Byzantium certainly merits further attention.

Gang Wu completed his doctoral studies at King's College London with a dissertation examining women in Byzantine Central Greece during the eleventh and the twelfth centuries. He was the postdoctoral fellow at Koç University's Research Center for Anatolian Civilizations (ANAMED) in 2020-2021. His current research focuses on the Byzantine silk industry, including its manufacturing processes, organisational structures and industrial networks.

120 In upper Egypt, see J. Sigl, 'Egyptian pit-looms from the late first millennium AD: attempts in reconstruction from the archaeological evidence', in M. Mossakowska-Gaubert (ed.), Egyptian Textiles and Their Production: 'word' and 'object' (Lincoln 2020) 22-35 (30-3). In Kato Vassiliki (Epiros), see

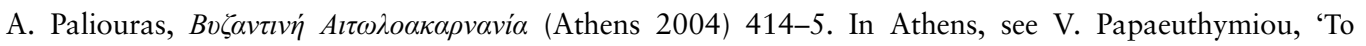

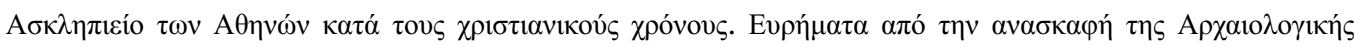

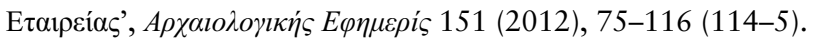

121 See n. 44. 